\title{
EDITORIAL
}

\section{Nova Scotia Science - Accomplishments and Challenges}

This PNSIS Issue and the ongoing series of monthly NSIS talks (2016-17) illustrate the range of science that is conducted in Nova Scotia and the region, and the amazing contributions that are celebrated continually across Canada and globally. The articles in this Issue cover topics that include the diversity of lichens and seaweeds found in Nova Scotia, the history of marine research, the importance of understanding changes in avian populations, advancements in management techniques in agriculture, insights into the process of discovery, and the requirement that scientific data be accessible to all potential users. Attention is drawn to two distinguished scientists, Arthur McDonald and Mary Ann White, noted for their special accomplishments and stellar careers. For the first time in recent issues of the Proceedings, reviews of two books prepared by local authors are included.

The various articles are just a thin slice of the many annual research contributions from the scientific and engineering communities in the province. Of special note recently is the award of the NSERC 2017 Gerhard Herzberg Canada, Gold Medal for Science and Engineering, to Dalhousie Physics Professor Jeff Dahn for his leading work in battery technology - the science of lithium-ion batteries. This is the third recent Herzberg award to a researcher in Atlantic Canada. Previous winners were W. Ford Doolittle (2013) and Axel Becke (2015), also of Dalhousie University. This is surely a home run in Maritime science!

Also noteworthy is the range of research conducted by young investigators, as shown by the contributions submitted each year to our student science writing competition, and the two excellent papers in this Issue by young investigators, Chen and Wilson, and by other young investigators in past years. This is so important - Nova Scotia must encourage and retain its highly educated young persons, as they will fuel the scientific breakthroughs, innovations, new products and a new and expanding economy for the region. Supporting all of this science requires political vision, leadership and investment for success. The Canadian federal government recognizes this fact, as well as the benefits of evidence-based/informed decision making, and to this 
end the government at various levels across Canada is reinvesting in science and science education.

That said, many scientific challenges are ahead of us as a society. For example, several environmental issues in Nova Scotia require new research and enhanced communication with the public and public officials. From my perspective as a marine scientist, these include: understanding the effectiveness of marine protected areas as they are established in our coastal waters; monitoring the potential environmental impacts of tidal power generation in the Bay of Fundy; and evaluating the potential risks of oil spills from tankers in the Bay of Fundy/Gulf of Maine and by offshore, deep water oil exploration and production. Other challenges include: interpreting recent Bay of Fundy fish and invertebrate kills, a localized and as yet unexplained mass mortality event; comprehensively addressing climate change and its threat to humanity (see Homer-Dixon's article); and finally, investigating the spread of micro-plastics and nano-particles in the ocean, and their potential effects on the marine ecosystem and human health.

Most of these problems require in-depth, longer term, fundamental and applied research, and an investment in people and institutions to ensure success. Every reader can certainly add numerous topics that require attention, some with similar urgency.

The annual NSIS lecture series presents a broad range of new science that is conducted in the region. This year, two talks on advancements in genomics were given - one by John Archibald on "molecular clocks: using DNA to infer evolution", and one by Graham Dellaire on "how to edit a genome". This research is changing the face of biology and medicine, and is just one example of the very active research conducted locally. Some of our invited speakers are also noted authors of popular science books. The reader is encouraged to pick up a copy of John Archibald's "One plus One equals One", a fascinating overview of symbiosis, endosymbiosis, and the evolution of complex life.

The NSIS continues to present a range of important topics in its annual lecture series. This is of increasing importance at this time of considerable political change and uncertainty in the western world. As Rush Holt, the CEO of the AAAS, has stated: "This is not the time to be timid or to keep our heads down. Evidence matters and decisions made with scientific input are far more likely to succeed. We all need to make sure this message is heard loud and clear". 
In Canada, we recently survived what some called "the war on science" under our last federal government (see previous editorials in PNSIS). We now have a government that understands the role of evidence in decision and policy making. It is supporting communication on scientific matters by its agencies and employees. In an age of false news ("alternative facts" and "post-truth"), NSIS has a vital role to play supporting the widest possible discussion of scientific, fact-based topics, essential for an informed society. Our annual lecture series is a critical communication mechanism both with respect to topics of interest and the role of scientists in providing factual information, i.e., evidence, to society as a whole.

It is hoped that the NSIS membership will grow and that its members will become engaged in the choice of future lecture topics. Debates also need to take place about science and its vital role in public policy making, in Canada and beyond. There is a role for both professional and citizen scientists in these endeavours. One of NSIS's most valuable contributions in future years will be to form bridges between these two groups, and between them and the general public, in the interests of our society and its long term well-being. The PNSIS continues to be one voice-piece in this on-going quest.

Acknowledgements A great many thanks are due to the NSIS Council for their work on the lecture program, the student competition, and other initiatives, and to Dr. David H. S. Richardson (Associate Editor), our editorial board, our reviewers, and Gail LeBlanc (Production/Layout Editor) in producing this Issue of the Proceedings. David Richardson is also thanked for his comments on this article.

\section{SELECTED BIBLIOGRAPHY}

AAAS. (American Association for the Advancement of Science). (2017). Stand up for Science. An announcement by R. D. Holt, CEO of the AAAS, Feb. $8^{\text {th }}, 2017$. Announcements @aaas.sciencepubs.org

Archibald, J. (2014). One plus One equals One. Symbiosis and the Evolution of Complex Life. Oxford University Press, Oxford, UK. (PB 2016). 209 pp.

Brock, R.J., Kenchington, E. \& Martinez-Arroyo, A. (Eds.). (2012). Scientific guidelines for designing resilient marine protected area networks in a changing climate. Commission for Environmental Cooperation, Montreal, Canada. 95 pp. 
Chiose, S. (2016). Education. Program defends science "in a world with many truths". Globe and Mail, Dec. 14, 2016. A14.

Farriers,A. (2017). Scientists pledge to avoid U.S. conferences. Chronicle Herald, Feb. $8^{\text {th }}$, p.A5.

Hannibal, M.E. (2016). Citizen Scientist. Searching for Heroes and Hope in an Age of Extinction. The Experiment, LLC, New York. 423 pp.

Homer-Dixon, T. (2017). Science. Canada must not give up the fight. Globe and Mail, Jan 2, 2017. A9.

Holt, R. (2017) Editorial. Act for science. Science 355(6325):551.

MacDonald, B.H., Soomai, S.S., De Santo, E. M., and Wells, P.G. (Eds.). (2016). Science, Information and Policy Interface for Effective Coastal and Ocean Management. CRC Press, Taylor and Francis, Boca Raton, FL. 474 pp.

Malakoff, D. (2017). A matter of fact. Science 355(6325):563.

Medawar, P.B. (1990). My life in science. Ch. 1 in The Threat and the Glory. Harper Collins Publ., New York.

PIPSC. (2014). Vanishing Science. The Disappearance of Canadian Public Interest Science. The Professional Institute of the Public Service of Canada, Ottawa, ON. 11 pp.

Semeniuk, I. (2017). Technology. Battery expert wins major prize. The Globe and Mail, Feb. $7^{\text {th }}$, p. A6.

Taleb, N.N. (2010). The Black Swan. The Impact of the Highly Improbable. Random House Trade Paperbacks, New York. 444 pp.

The Editors of Scientific American. (2017). A letter to Washington. Sci. Amer. 316(2):7.

Tory, S. (2017). In Canada, a move to protect data from Trump. High Country News, Jan. 10 2017.

Vernon, J.L. (2017). Science in the post-truth era. Amer. Sci. 105 (1):2.

Wells, P.G. (2016). Do marine protected areas work - lessons learned? The Canadian Society of Environmental Biologists, Newsletter/Bulletin 73(4):12-13.

Wells, P.G. (2017). The iconic Torrey Canyon oil spill of 1967 - marking its legacy. Mar. Pollut. Bull. 115 (1-2):102.

P.G. Wells, Dalhousie University

Editor, PNSIS 